Original Research Paper

\title{
Hormonal and Histopathological Alterations in Pituitary Glands and Reproductive Organs of Male and Female Mice Orally Inoculated with Pasteurella Multocida Type B: 2 and its Lipopolysaccharides
}

\author{
${ }^{1,2}$ Faez Firdaus Jesse Abdullah, ${ }^{1,3}$ Lawan Adamu, ${ }^{1,3}$ Abdulnasir Tijjani, ${ }^{1,3}$ Konto Mohammed, \\ ${ }^{1,3}$ Yusuf Abba, ${ }^{1,3}$ Muhammad Abubakar Sadiq, ${ }^{1}$ Rosmawati Zainal, ${ }^{1}$ Muhammad Jamil Bin Sabu, \\ ${ }^{1}$ Abdul Aziz Saharee and ${ }^{1,2}$ Abdul Wahid Haron \\ ${ }^{I}$ Department of Veterinary Clinical Studies, Faculty of Veterinary Medicine, \\ Universiti Putra Malaysia, 43400 UPM Serdang, Selangor, Malaysia \\ ${ }^{2}$ Research Centre for Ruminant Disease, Faculty of Veterinary Medicine, \\ Universiti Putra Malaysia, 43400 UPM Serdang, Selangor, Malaysia \\ ${ }^{3}$ Faculty of Veterinary Medicine, University of Maiduguri, P.M.B. 1069, Borno State, Nigeria
}

Article history

Received: 12-07-2014

Revised: 29-10-2014

Accepted: 01-11-2014

Corresponding Author: Faez Firdaus Jesse Abdullah Department of Veterinary

Clinical Studies,

Faculty of Veterinary

Medicine,

Universiti Putra Malaysia,

43400 UPM Serdang,

Selangor, Malaysia

Tel: +60175550870

E-mail: jesseariasamy@gmail.com

\begin{abstract}
Oral infections of mice as animal model with Pasteurella multocida type B: 2 and its lipopolysaccharides is liable to cause detrimental alterations in the pituitary glands, which results in disruption of reproductive hormonal levels as well as organ functions in the male and female animals; thereby impeding the fertility of at risk animal population. Therefore, this study was designed to evaluate the histopathological modifications in the pituitary glands, reproductive organs and the associated hormonal levels in male and female mice inoculated orally with P. multocida type B: 2 and its lipopolysaccharides. Forty eight mice were divided into three groups consisting of sixteen mice each $(8$ male and 8 female in separate cages). Group 1 served as the control group and were inoculated orally with $0.4 \mathrm{~mL}$ Phosphate Buffer Saline (PBS), group 2 were inoculated orally with $0.4 \mathrm{~mL}$ of $10^{9}$ Colony Forming Unit (CFU) of $P$. multocida type B: 2 while group 3 were inoculated orally with $0.4 \mathrm{~mL}$ of LPS from $10^{9}$ of colony P. multocida type B: 2 . There were significant differences $(\mathrm{p}<0.05)$ in the lesions (oedema, haemorrhage, degeneration and necrosis) observed in the testes, ovaries and the pituitary glands amongst the three groups. Similarly, there were significant differences in the levels of testosterone, progesterone and estrogen $(\mathrm{p}<0.05)$ in the male and female mice inoculated orally with $P$. multocida type B: 2 and its lipopolysaccharide. There is paucity of information on changes related to reproductive hormones, pituitary glands and reproductive organs of male and female mice following oral inoculation with $P$. multocida type B: 2 and its endotoxin. Hence, the sex hormonal levels could be used to assess the immune statuses of at risk animal population and proffer amenable Veterinary medical care to afflicted animal population.
\end{abstract}

Keywords: Pasteurella Multocida, Lipopolysaccharide, Pituitary Glands, Reproductive Organs, Hormonal

\section{Introduction}

Haemorrhagic Septicaemia (HS) is an important disease in African and Asian countries including Malaysia caused by Pasteurella multocida type B: 2 which has high mortality and morbidity (Jamal et al., 2005; OIE, 2008). It can be described as acute, fatal septicaemic disease caused by specific serotypes of Pasteurella multocida. Based on the component of the outer cells layer, $P$. multocida is grouped into 5 capsular 
types which are A, B, D, E and F (Shafarin et al., 2009). Serotypes B: 2 and E: 2 are the most recognized in Asia and Africa based on Carter and Hendleston system (OIE, 2008). HS is predominantly found in cattle and buffaloes whereas buffaloes are more susceptible than cattle (Saharee, 2006; Abubakar and Zamri, 2011). Younger animals were reported to succumb to HS more readily than older animals (Boyce et al., 2010; Harper et al., 2011). The important feature of $P$. multocida type B: 2 that is able to cause HS is its capability to synthesize the enzyme hyalurinidase (OIE, 2008). The clinical signs include rapid course, increase in temperature, hypersalivation, loud and stertorous breathing due to oedematous swelling, petechial haemorrhages in the throat and brisket region. It also involves nasal discharge, swellings in the submandibular region until brisket area and death within $24 \mathrm{~h}$ (Saharee, 2006), unless they are treated at the very early stage of the disease (Moffatt et al., 2010). Morbidity and mortality in HS depends on the immunological status of the individual or groups of animals with the disease (Boyce et al., 2010).

The organism is a small gram negative, non-motile and non-spore-forming bacterium. They are coccobacili with bipolar staining abilities mostly taking up Leishman or methylene blue stain which make it distinguishable from other Pasteurella organisms (Jamal et al., 2005). The colonyis one millimetre in diameter with slightly raised centre and with a glistening lustre (Harper et al., 2011). P. multocida type B: 2 produces oxidase, catalase, indole and trifling quantity of nitrates. It does not produce hydrogen sulphate or urase and fail to utilize citrate or liquefy gelatine and grows aerobically in an ordinary nutrient agar (OIE, 2008).

The gram negative bacteria $P$. multocida type $\mathrm{B}: 2$ is composed of Lipopolysaccharide (LPS) structure. The LPS is an important component of the outer cell wall of the organism (Eckersall and Bell, 2010; Moffatt et al., 2010; Harper et al., 2011). They are released during multiplication or bacterial deaths that lead to an inflammatory reaction. It represents the endotoxins of the organism and in principle responsible for toxicity in HS and also plays an important role in the pathogenesis of the disease (Raetz et al., 2002; Jesse et al., 2013).

Rainwater and rivers also play an important role in disease transmission, assisting in the dissemination and transfer of infection to areas downstream (Khaleel et al., 2013). Rivers and streams have been thought to be responsible for the transmission of haemorrhagic septicemia through carcasses washed down from one village upstream to another further down the rivers (Khaleel et al., 2013). In fact HS has been associated with the monsoon seasons (Abdullah et al., 2013a) and dumping of infected carcasses into streams and rivers.

Khaleel et al. (2014) Stated that there is dissemination and multiplication of $P$. multocida B: 2 in vital organs after intranasal and subcutaneous challenge in mice.
According to a previous study of HS by (OIE, 2008) using mice as animal model, oral inoculation of $P$. multocida type B: 2 in mice produced pathological lesions and also intraperitoneal inoculation of $P$. multocida type B: 2 and its LPS in male mice showed significant changes in male reproductive organs. However, there is paucity of knowledge on information regarding changes in the reproductive hormones, pituitary glands and reproductive organs of male and female mice after oral inoculation with $P$. multocida type B: 2 and its endotoxin. Therefore, this study was designed to evaluate the histopathological changes in the reproductive organs, pituitary glands and reproductive hormones of the male and female mice following oral inoculation with $P$. multocida type B: 2 and its Lipopolysaccharides (LPS).

\section{Materials and Methods}

\section{Experimental Mice}

Forty eight healthy ICR male and female mice aged 3 weeks old were used in this study. All the mice were obtained from Institute of Cancer Research (ICR) and were kept at the Animal Research Center, Universiti Putra Malaysia (UPM) and housed in plastic cages. Six plastic cages were used, where each cage consist of 8 mice. The mice were fed with commercial pellet and provided water ad libitum. All the mice were observed for one week for acclimatization to the new environment and to make sure they were healthy prior to the experiment. All procedures and experiments illustrated were undertaken under a project license approved by Animal Utilization Protocol Committee, Faculty of veterinary medicine, Universiti Putra Malaysia, with reference number: PM/IACUC/FYP2013/FPV.043 and FPV/FYP/2013/059

\section{Inoculums}

The wild type $P$. multocida type B: 2 that were used in this study was obtained from stock culture from Veterinary Research Institute Ipoh Perak. Identification of P. multocida type B: 2 was done using the Gram staining method and biochemical characterization of oxidase, urea broth, Sulphur Indole Motility (SIM), Triple Sugar Iron (TSI) and citrate test, to confirmed the isolate as $P$. multocida type B: 2 . The pure stock culture that was stored on nutrient agar slants were subcultured on $5 \%$ horse blood agar and incubated at $37^{\circ} \mathrm{C}$ for $18 \mathrm{~h}$. A single colony of the P. multocida type B: 2 was selected to grow on Brain Heart Infusion (BHI) broth, incubated in shaker incubator at $37^{\circ} \mathrm{C}$ for $24 \mathrm{~h}$ before the concentration was determined using McFarland Nephelometer Barium Sulfate Standards.

\section{Preparation of $10^{9}$ CFU of P. multocida Type B: 2}

Preparation of $10^{9}$ Colony Forming Unit (CFU) of $P$. multocida was done by adding distilled water onto pure 
cultures of $P$. multocida before the bacteria was transferred into sterile test tubes. These sterile test tubes were then compared with McFarland standard to determine the $10^{9} \mathrm{CFU}$ of $P$. multocida.

LPS Extraction from $10^{9}$ of Colony of P. Multocida Type B: 2

The Lipopolysaccharides (LPS) of $P$. multocida type B: 2 was extracted using Intron Biotechnology ${ }^{\circledR}$ LPS extraction kit. In this study, $10^{9} \mathrm{CFU}$ of $P$. multocida type B: 2 was prepared for LPS extraction. The bacteria were first harvested by centrifugation in room temperature at $13,000 \mathrm{rpm}$ for $30 \mathrm{sec}$. Then, $1 \mathrm{~mL}$ of lysis buffer was added and vortex vigorously. $200 \mu \mathrm{L}$ of choloform was later added and vortex vigorously for 10-20 sec before it was incubated for $5 \mathrm{~min}$ in room temperature. It was then centrifuged at 13,000 rpm for $10 \mathrm{~min}$ at $4^{\circ} \mathrm{C}$ and $400 \mu \mathrm{L}$ of the supernatant was transferred into a new $1.5 \mathrm{~mL}$ tube. About $800 \mu \mathrm{L}$ of purification buffer was added and mixed well with the transferred supernatant after which it was incubated at $20^{\circ} \mathrm{C}$ for $10 \mathrm{~min}$. It was then centrifuged again at 13,000 rpm for $15 \mathrm{~min}$ at $4^{\circ} \mathrm{C}$. The LPS pellet was obtained after the excess supernatant was discarded before the LPS pellet was washed with $1 \mathrm{ml}$ of $70 \%$ ethanol, which was then dried completely. Finally, $70 \mu \mathrm{L}$ of $10 \mathrm{mM}$ Tris- $\mathrm{HCl}$ buffer of $\mathrm{pH} 8.0$ was added to the LPS pellet whereby it was dissolved by 2 min of boiling.

\section{Study Designs}

Forty eight mice were divided into three groups of sixteen mice each; of eight Male (M) and eight Female (F) mice each. Group 1served as the negative control group and were inoculated orally with $0.4 \mathrm{~mL}$ Phosphate Buffer Saline (PBS), group 2 were inoculated orally with $0.4 \mathrm{~mL}$ of $10^{9}$ Colony Forming Unit (CFU) P. multocida type B: 2 and group 3 were inoculated orally with $0.4 \mathrm{~mL}$ of LPS from $10^{9}$ of colony P. multocida type B: 2 . After inoculation, all the groups were observed for 10 days. Mice that showed severe clinical signs, such as laboured breathing, reduction in responsiveness and those with closed eyes were euthanized by cervical dislocation to minimize suffering and blood was collected via cardiac venipuncture to determine the reproductive hormones concentrations using radioimmunoassay technique. On day 10 , all the survived mice were also euthanized using the same technique. Post-mortem was conducted on all the euthanized mice, the organs of interest were the brain, testis, ovaries and pituitary glands. These organs were collected and put into $10 \%$ formalin before being processed. Tissue was processed into paraffin blocks and each section was routinely stained with standard hematoxylin and eosin $(\mathrm{H}$ and $\mathrm{E})$ stain for histopathological study. Gross pathological lesions were examined during the post-mortem.

\section{Histopathology Lesions Scoring}

The histological slide of each organ was examined under light microscope and the histopathological lesions were scored by taking six different views using 400 times magnification. The lesions were classified into 4 different scores, which are " 0 " for normal, " 1 " for mild, " 2 " for moderate and " 3 " for severe lesions. The lesions were considered as "normal" if less than $30 \%$ of the field was affected, mild if only $30 \%$ of the field was affected, moderate if $60 \%$ of the field was affected and severe if more than $60 \%$ of the field was affected. Lesions that were scored are necrosis and degeneration, oedema, haemorrhage as well as presence of inflammatory cells.

\section{Blood Collection for Reproductive Hormone Analysis}

One $\mathrm{ml}$ of blood was collected from the mice via intracardiac venipuncture using plain tube after 10 days of experiment. The blood sample collected was used for the determination of the reproductive hormones specifically for testosterone, estrogen and progesterone concentrations. Then, the blood was centrifuged at $15,000 \mathrm{rpm}$ for $10 \mathrm{~min}$ to separate the serum and was transferred into the Eppendorf tubes. After that, the testosterone, progesterone and estrogen level were analyze using Radioimmunoassay kits by Beckman Coulter.

\section{Radioimmunoassay Technique for the Determination of Testosterone}

To determine hormone concentration, radioimmunoassay of testosterone was conducted using serum from the blood sample collected from each mouse. Firstly, the addition step was performed where 50 microlitre of calibrator mixed with 500 microlitre of tracer and added to antibody coated tubes. After that, cover tubes was incubated for $1 \mathrm{~h}$ at $37^{\circ} \mathrm{C}$ in water bath. The last step was counting count bound per minute using Wallac Wizard Gamma Counter model 1470.

\section{Radioimmunoassay Technique for the Determination of Estrogen and Progesterone}

The female reproductive hormones were analyzed were estrogen and progesterone. These hormones were analyzed using Radioimmunoassay (RIA) by Beckman Coulter. Serum was used for hormone analysis. First, 100 $\mu \mathrm{L}$ of calibrator, control or plasma from the mice blood were mixed with $500 \mu \mathrm{L}$ of the tracer. Then, the mixture was incubated at $18-25^{\circ} \mathrm{C}$ with vibration at $350 \mathrm{rpm}$. The incubation duration for estrogen was $3 \mathrm{~h}$ while for progesterone only $1 \mathrm{~h}$. After that, counting step was done by count Bound of cpm (B) and Total cpm (T) for $1 \mathrm{~min}$ using automatic gamma counter machine by Wallac Wizard Gamma Counter model 1470. 


\section{Statistical Analysis}

SPSS version 20 was used to analyze the data collected. The lesions scoring were analyzed using Kruskal-Wallis test. Comparisons between groups were considered significant at $\mathrm{p}<0.05$ using Mann-Whitney test.

\section{Results}

\section{Histopathological Findings}

In the male mice group, the testis and pituitary gland were examined for histopathogical changes. The lesions examined were the presence of necrosis and degeneration, oedema, haemorrhages and inflammatory cells. The result showed that there were significant differences $(p<0.05)$ in the lesions scored amongst the three groups of male mice (Fig. 1). The mean concentration of testosterone in Group 2 was twofold higher compared to Group 1 and Group 3 (Fig. 2). Figure 5 to 10 showed the histopathological alterations in the testis and pituitary gland of male mice inoculated orally with $P$. multocida type B: 2 and its lipopolysaccharide.
Furthermore, in the female mice group, the ovaries and pituitary gland were evaluated for histopathological alterations. The lesions evaluated were necrosis and degeneration, oedema, haemorrhages and inflammatory cells. The result showed that there were significant differences $(\mathrm{p}<0.05)$ in the lesions scored amongst the three groups of female mice; the control (PBS) and the treatments groups 2 and 3 except in oedema where there was no significant alterations (Table 1 to 4 ). The results showed significant increase $(p<0.05)$ in progesterone concentrations in group 3 compared to group 2 and 1. There was a significant decrease $(p<0.05)$ in the concentrations of estrogen in group 2 compared togroups 1 and 3 . The progesterone and estrogen concentrations in the female mice infected with PBS, P. multocida type B: 2 and LPS are shown in Fig. 3 and 4. Additionally, Figure 11 to 19 showed the histopathological alterations in the ovaries and pituitary gland of female mice inoculated orally with P. multocida type B: 2 and its lipopolysaccharide.

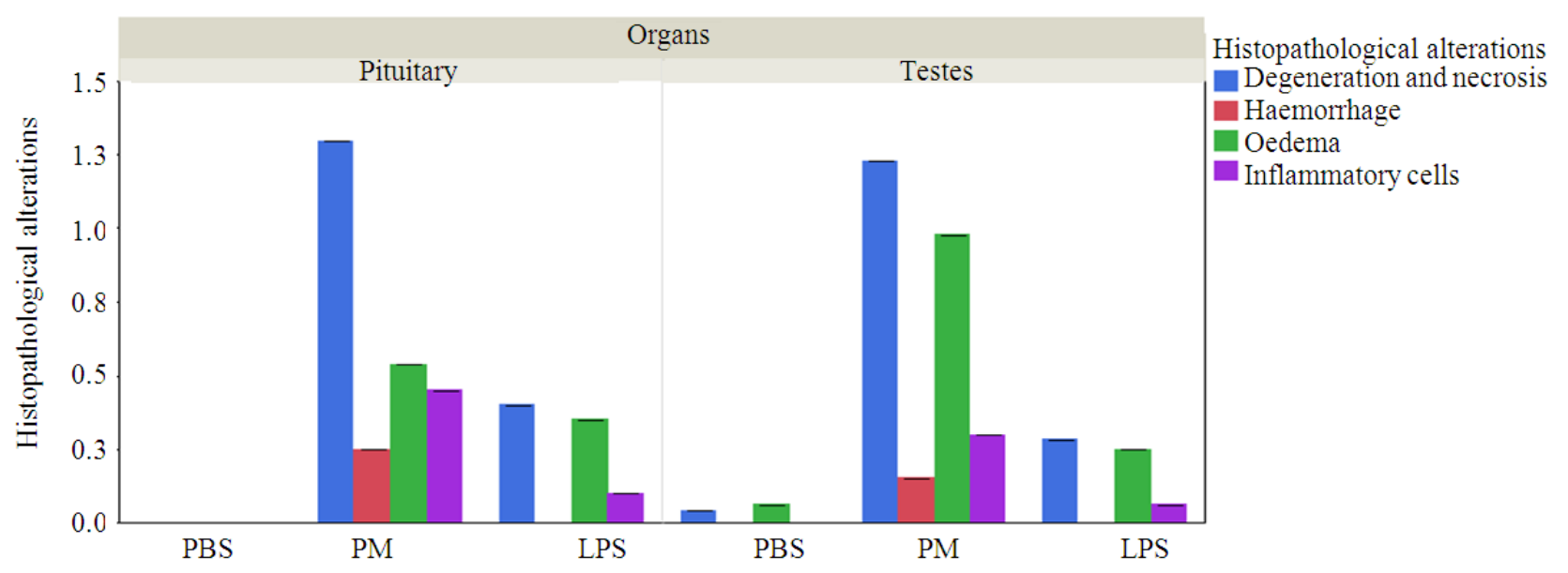

Fig. 1. Histopathological changes in the pituitary gland and testes in the PBS, PM and LPS groups of male mice; PBS = Phosphate Buffered Saline; PM = P. Multocida type B: 2; LPS = Lipopolysaccharide

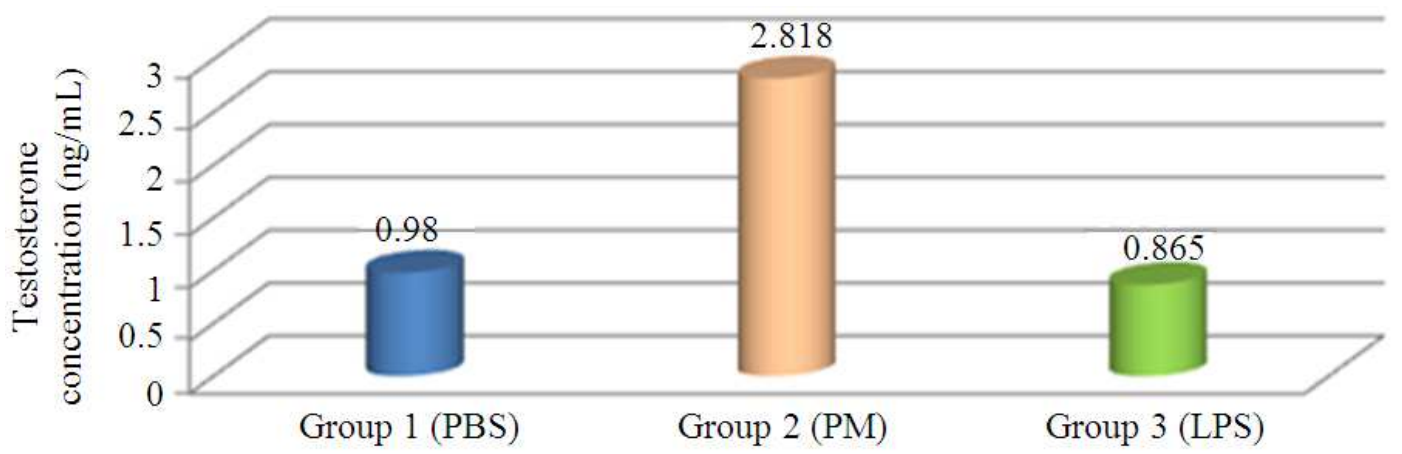

Fig. 2. Mean testosterone concentration in the various groups of the male mice; Group 1= Control group; Group 2 and 3 are the inoculated groups; PBS = Phosphate Buffered Saline; PM = P. Multocida type B: 2; LPS = Lipopolysaccharide 


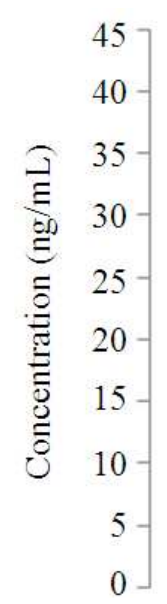

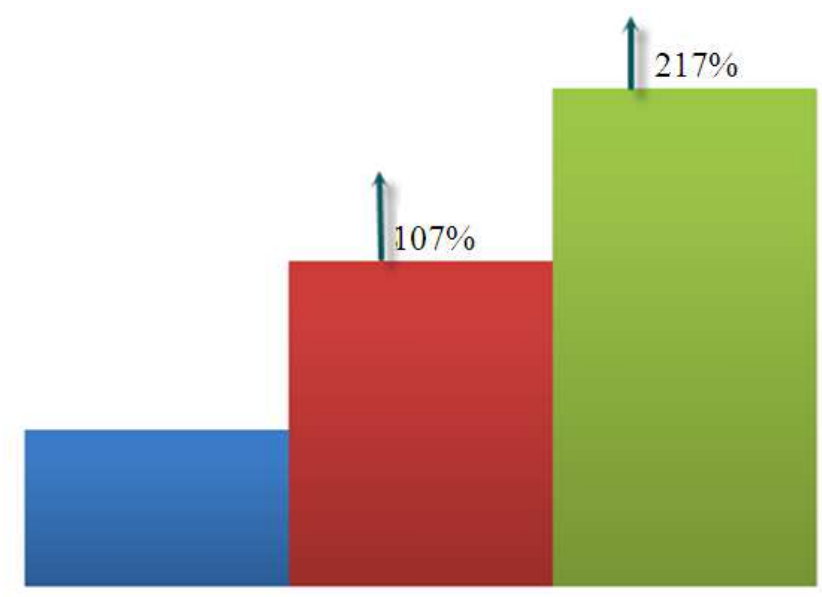

Fig. 3. Mean progesterone concentration in female mice; PBS $=$ Phosphate Buffered Saline; PM $=$ P. Multocida type B: 2; LPS $=$ Lipopolysaccharide

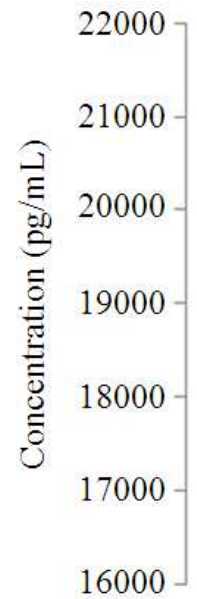

Fig. 4. Mean Estrogen concentration in female mice; PBS = Phosphate Buffered Saline; PM = P. Multocida type B: 2; LPS = Lipopolysaccharide

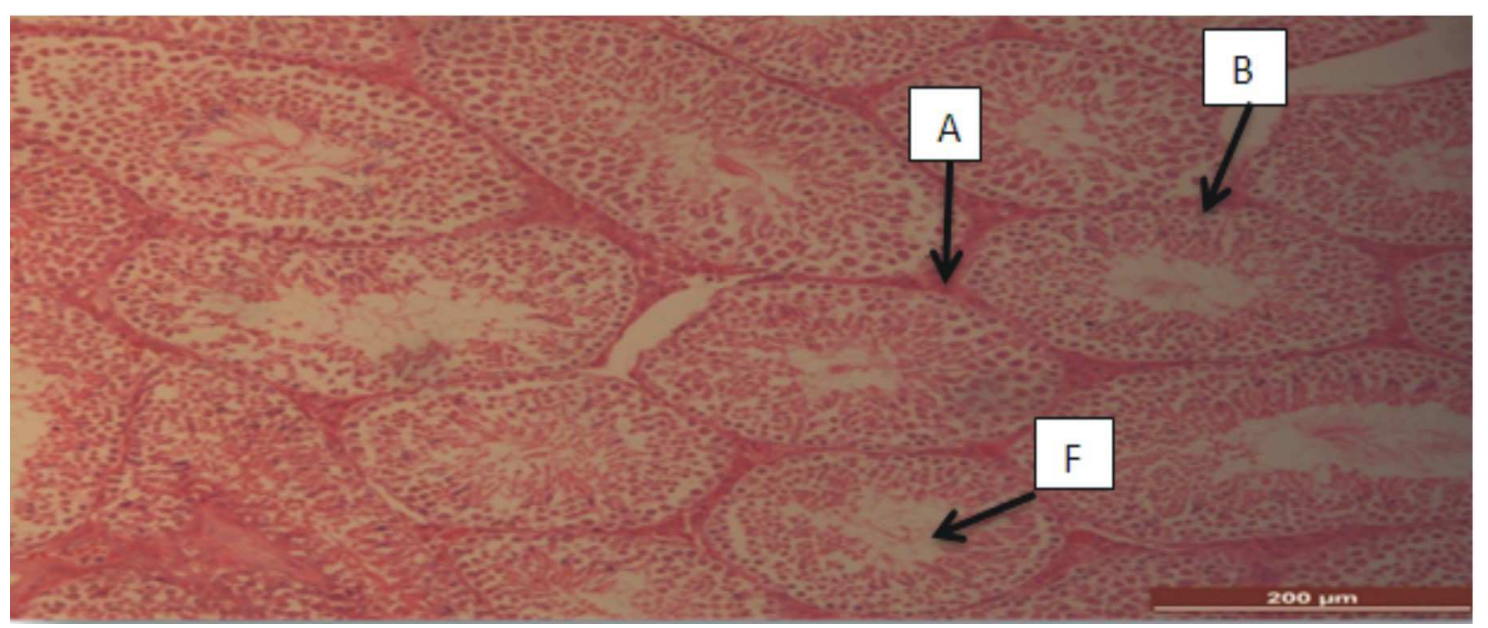

Fig. 5. Photomicrograph section of the testis of male mice in group 1. Leydig cells (A); Sertoli cell (B) and lumen of seminiferous tubules $(\mathrm{F}) ; \mathrm{H} \& \mathrm{E} \times 200$ 


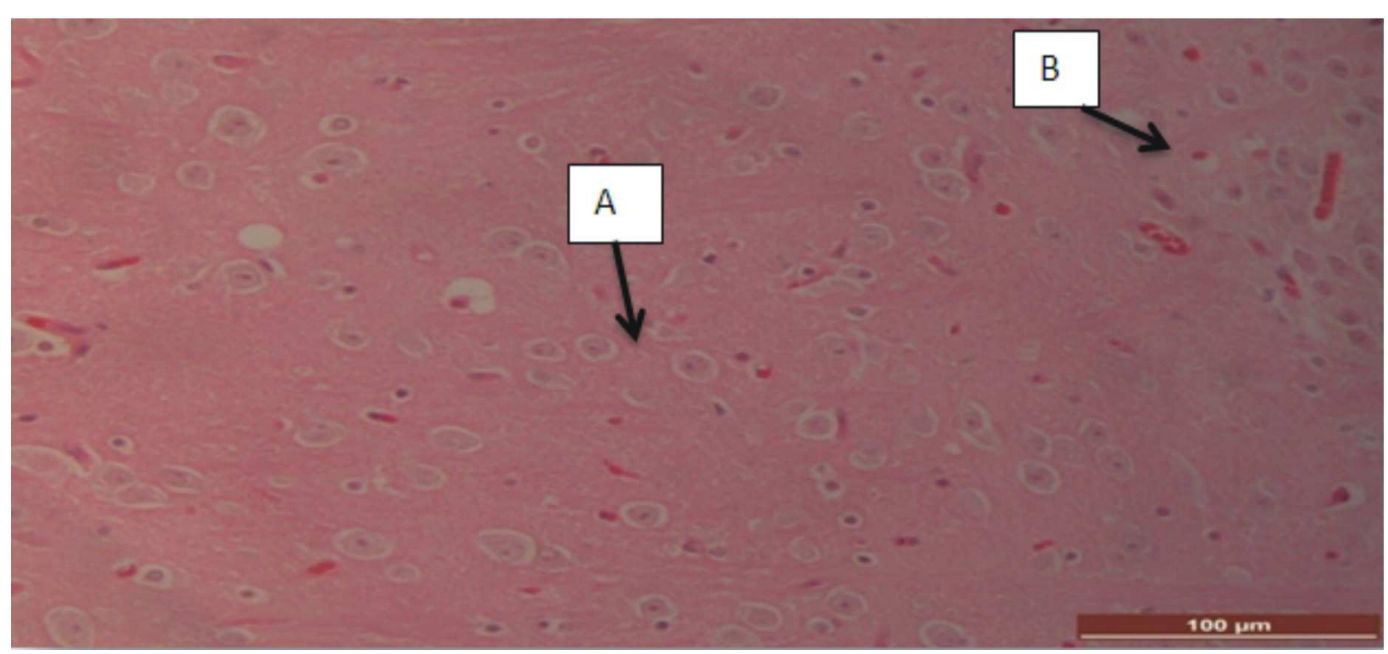

Fig. 6. Photomictograph section of the pituitary gland of the male mice in group 2 ; H\&E $\times 200$

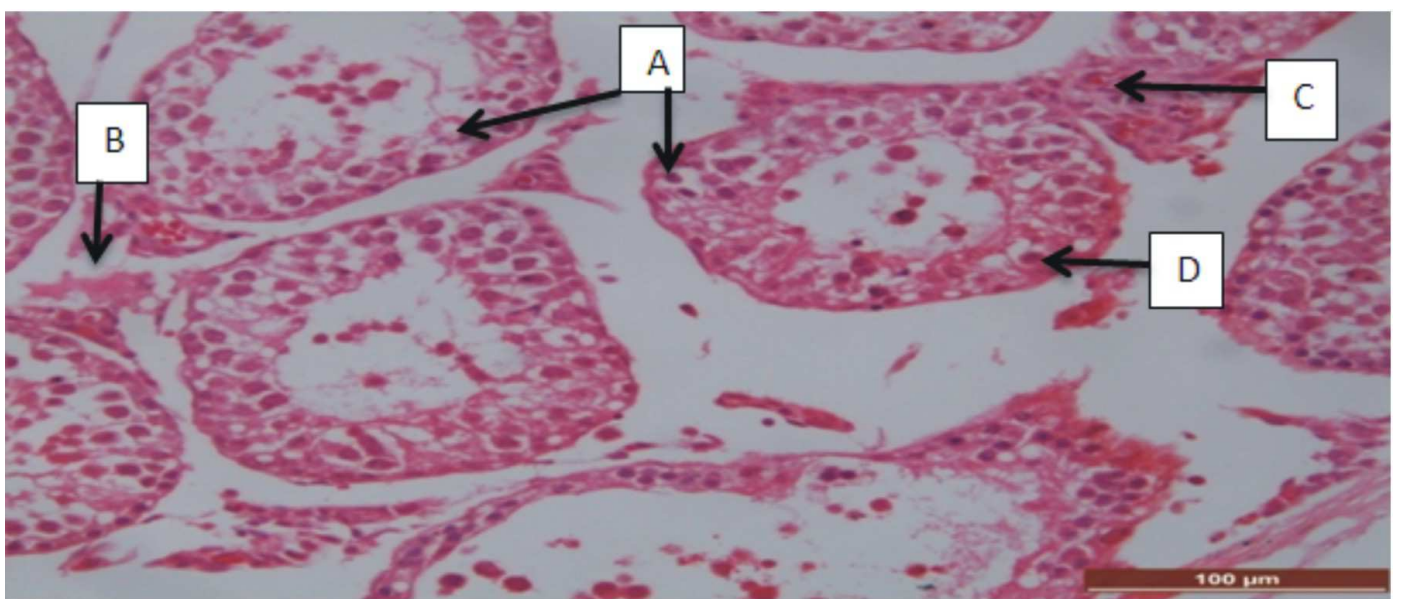

Fig. 7. Photomicrograph section of testis of the male mice in group 2. Area of necrosis and degeneration (A); Oedema (B); Haemorrhage $(C)$ and inflammatory cells $(D)$; H\&E $\times 200$

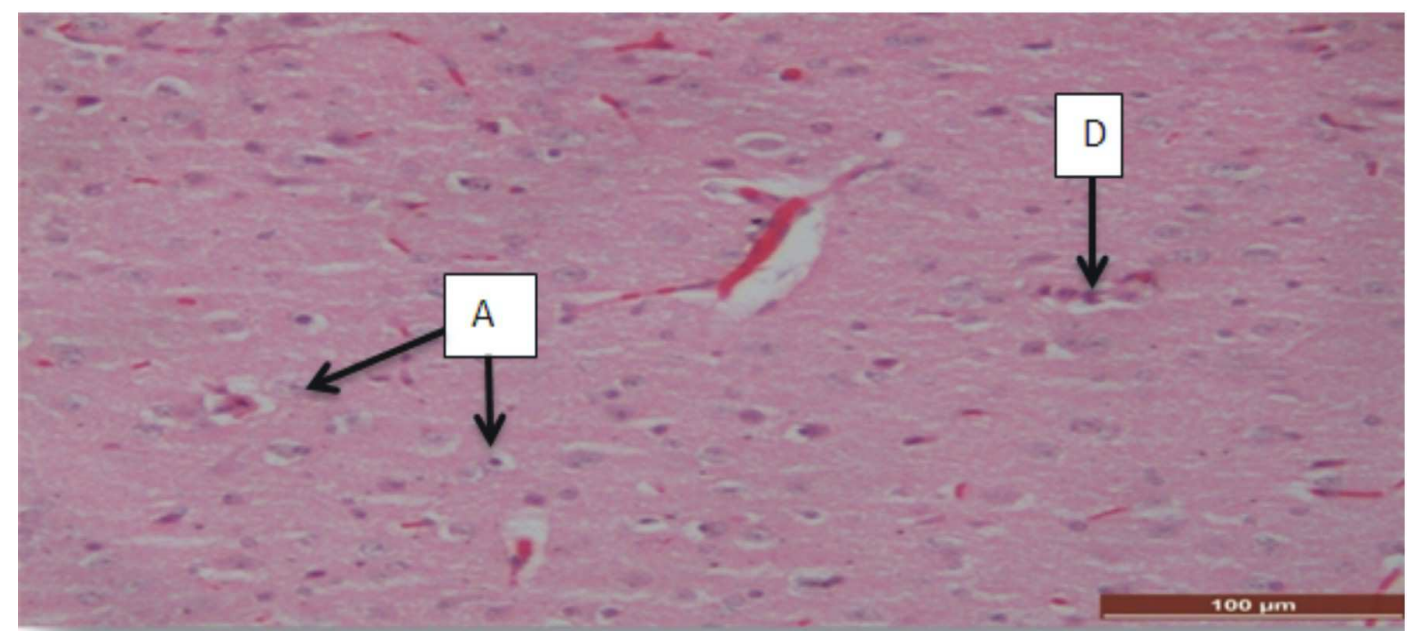

Fig. 8. Photomicrograph section of pituitary gland of male mice in group 2. Area of necrosis and degeneration (A) and inflammatory cells (D); H\&E $\times 200$ 


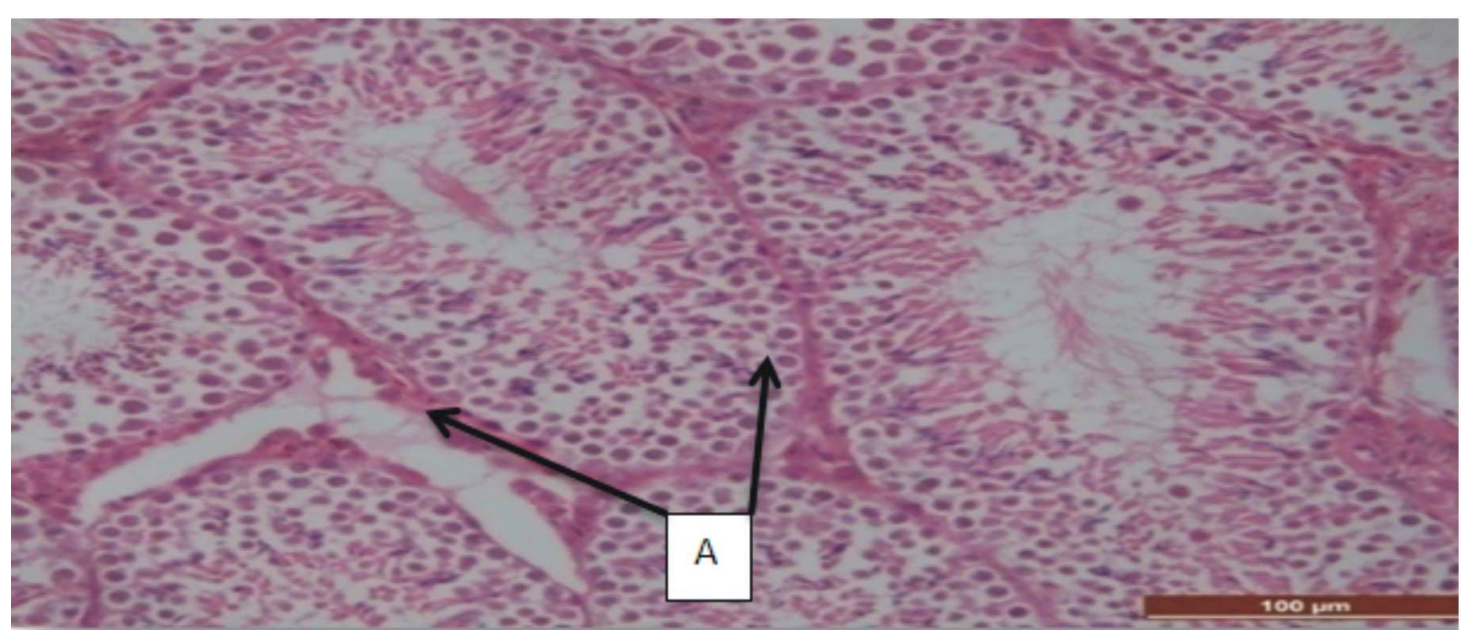

Fig. 9. Photomicrograph section of testis of male mice in group 3 , showing area of necrosis and degeneration (A); $H \& E \times 200$

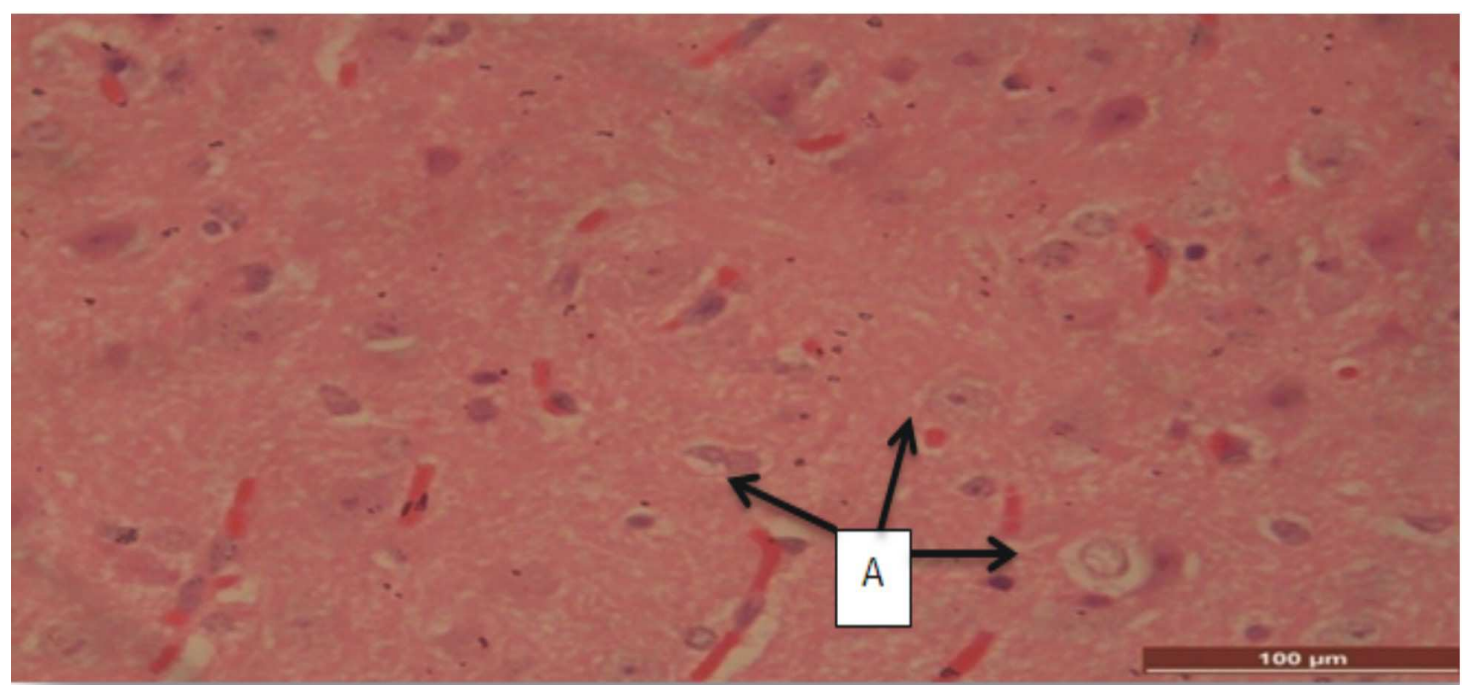

Fig. 10. Photomicrograph section of pituitary gland of group male mice showing area of necrosis and degeneration (A), $H \& E \times 200$

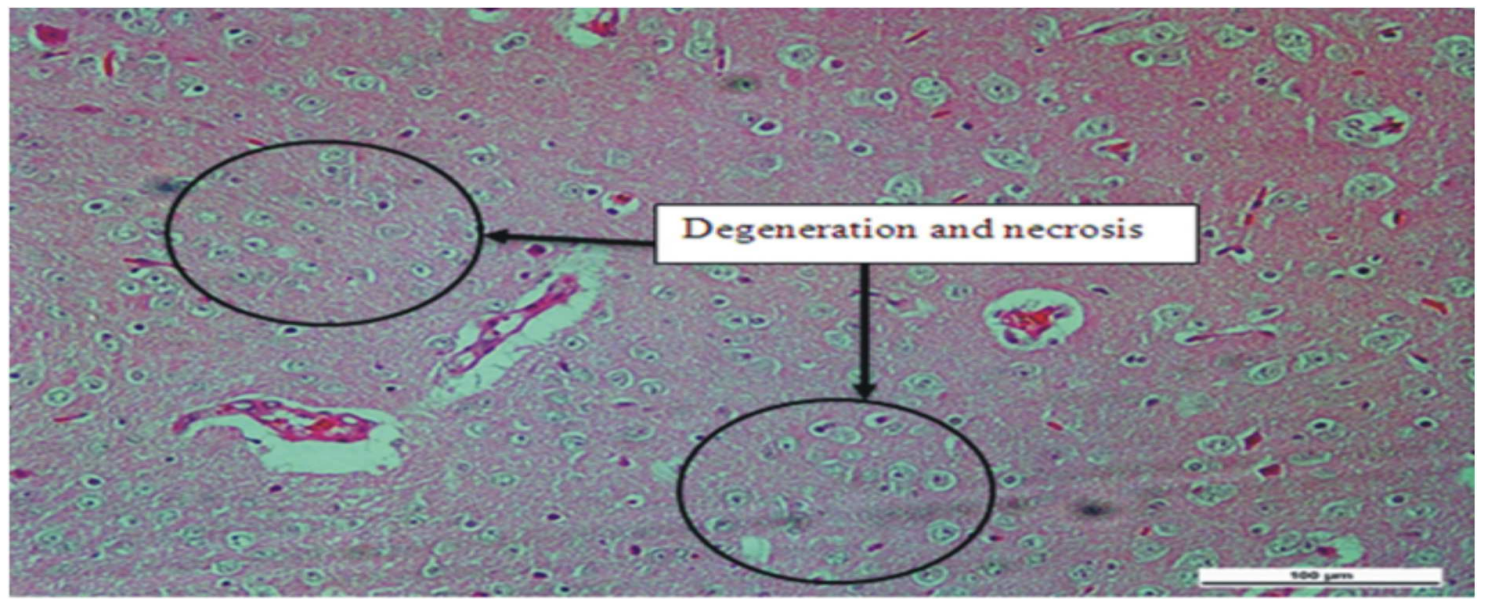

Fig. 11. Photomicrograph of a section of pituitary gland of female mice infected with P. multocida type B: 2 which showed swelling of the cells and some pyknosis indicating degeneration and necrosis, $\mathrm{H} \& \mathrm{E} \times 200$ 


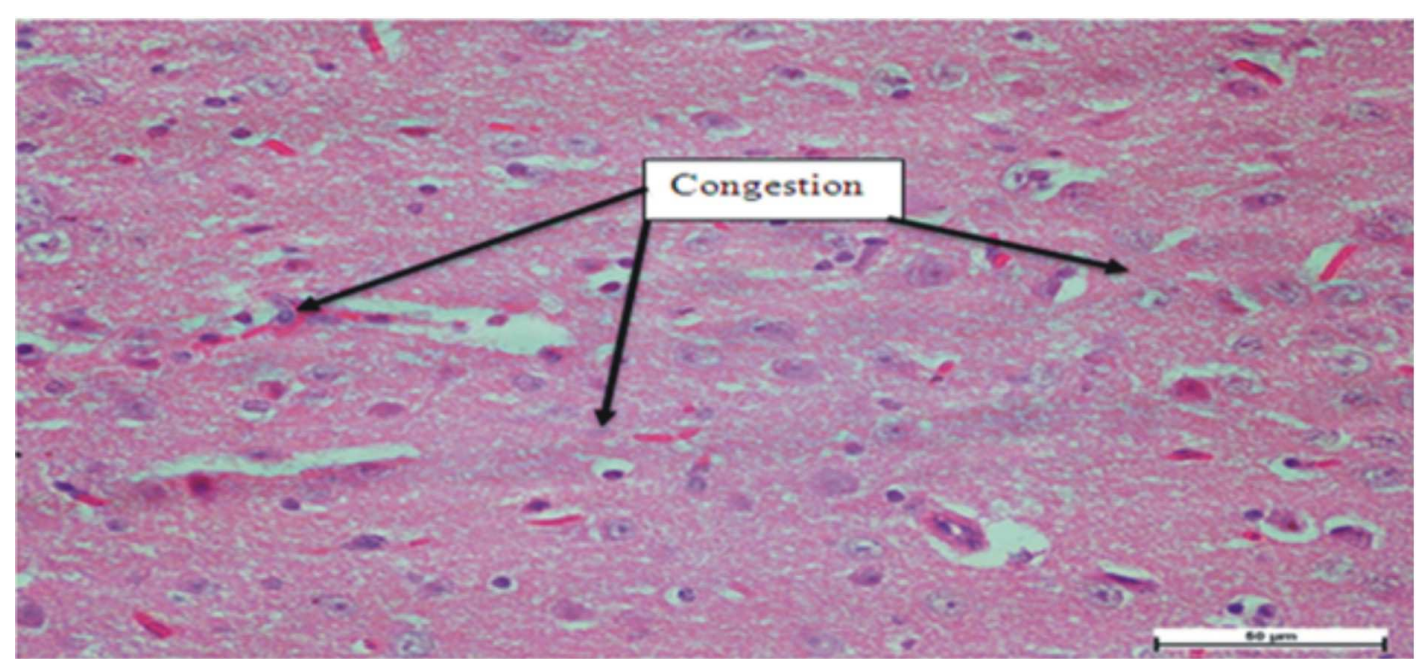

Fig. 12. Photomicrograph section of the pituitary gland which showed congested blood vessels in female mice inoculated with P. multocida type $\mathrm{B} ; \mathrm{H} \& \mathrm{E} \times 200$

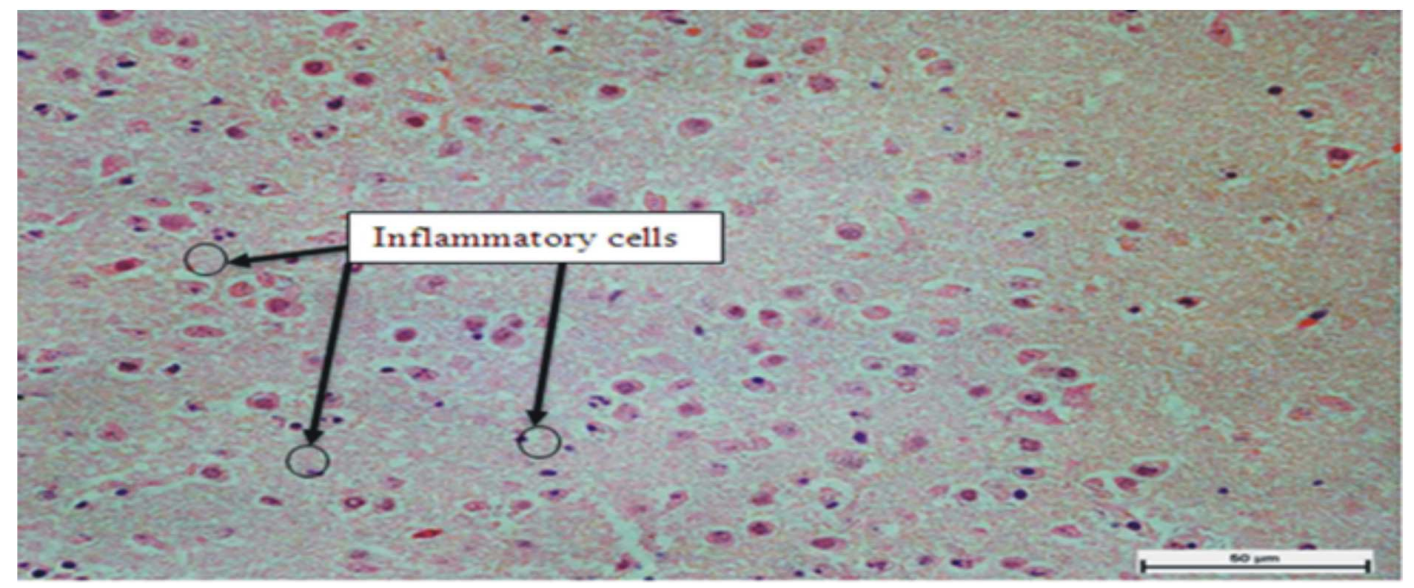

Fig. 13. Photomicrograph section of the pituitary gland which showed infiltrations of inflammatory cells in female mice infected with P. multocida type B; H\&E $\times 200$

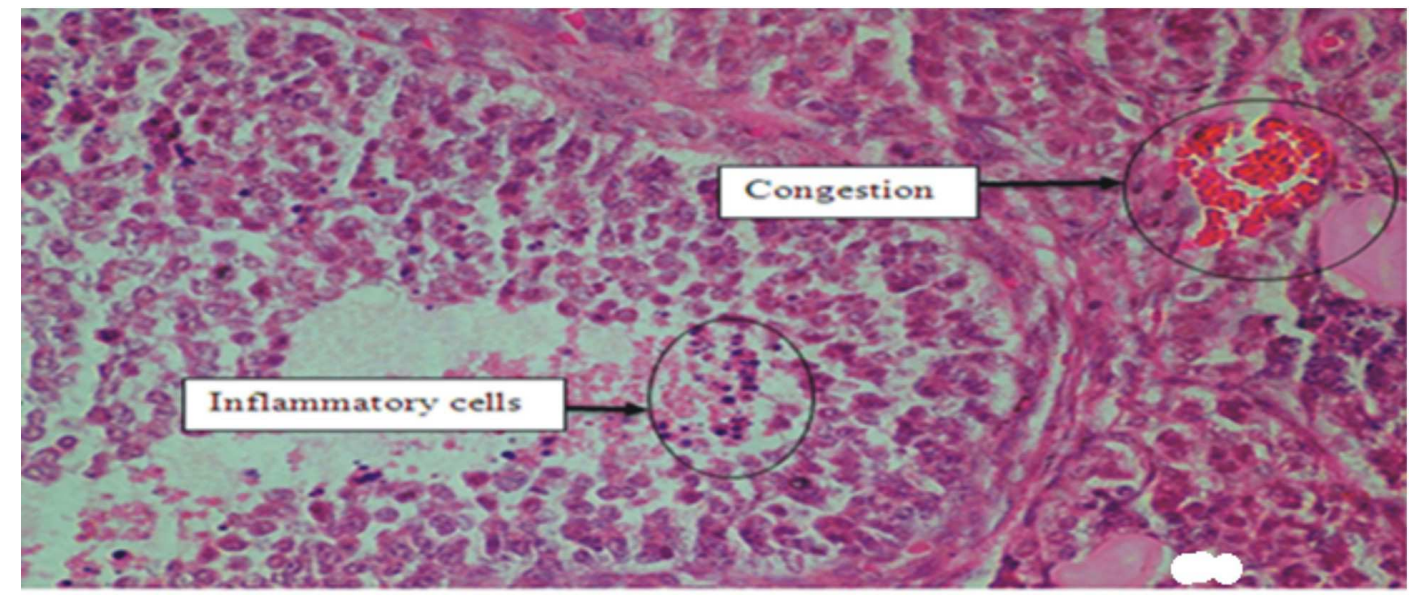

Fig. 14. Photomicrograph section of the ovary which showed infltrations of inflammatory cells with severe congestions of the blood vessels in female mice inoculated with P. multocida type B; H\&E $\times 200$ 


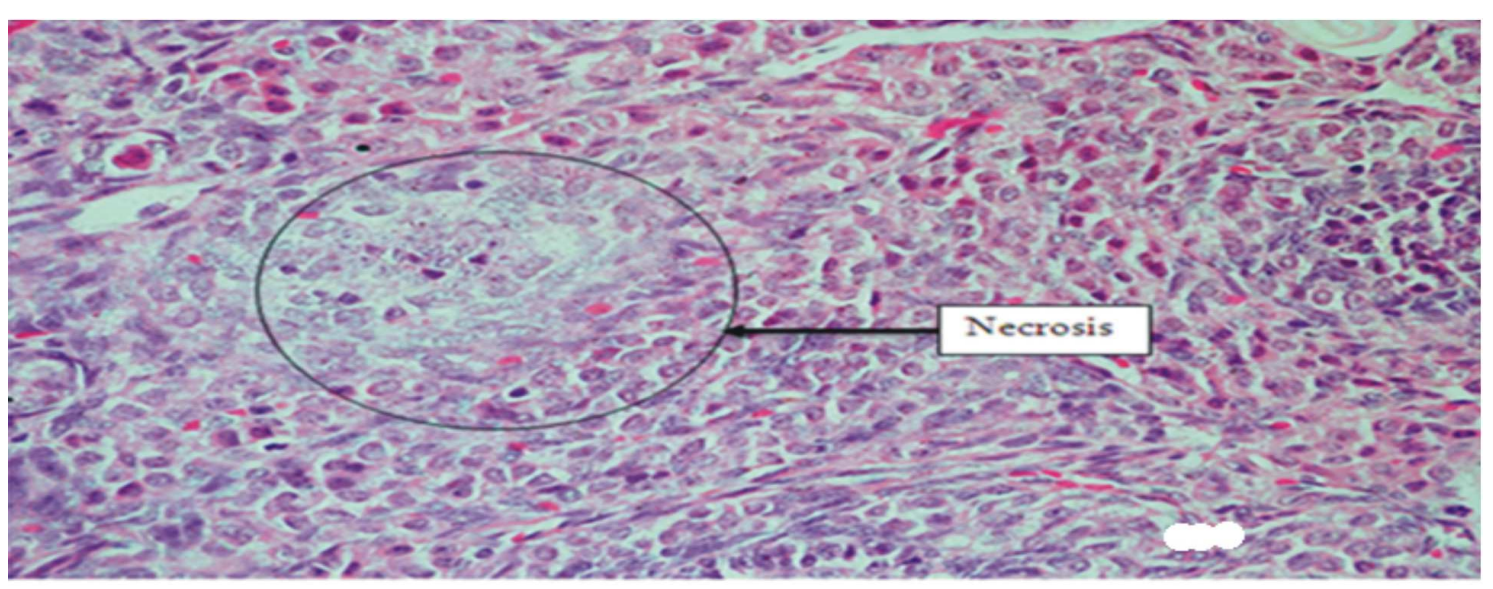

Fig. 15. Photomicrograph section which showed necrosis in some parts of the ovary in female mice inoculated with $P$. multocida type $\mathrm{B} ; \mathrm{H} \& \mathrm{E} \times 200$

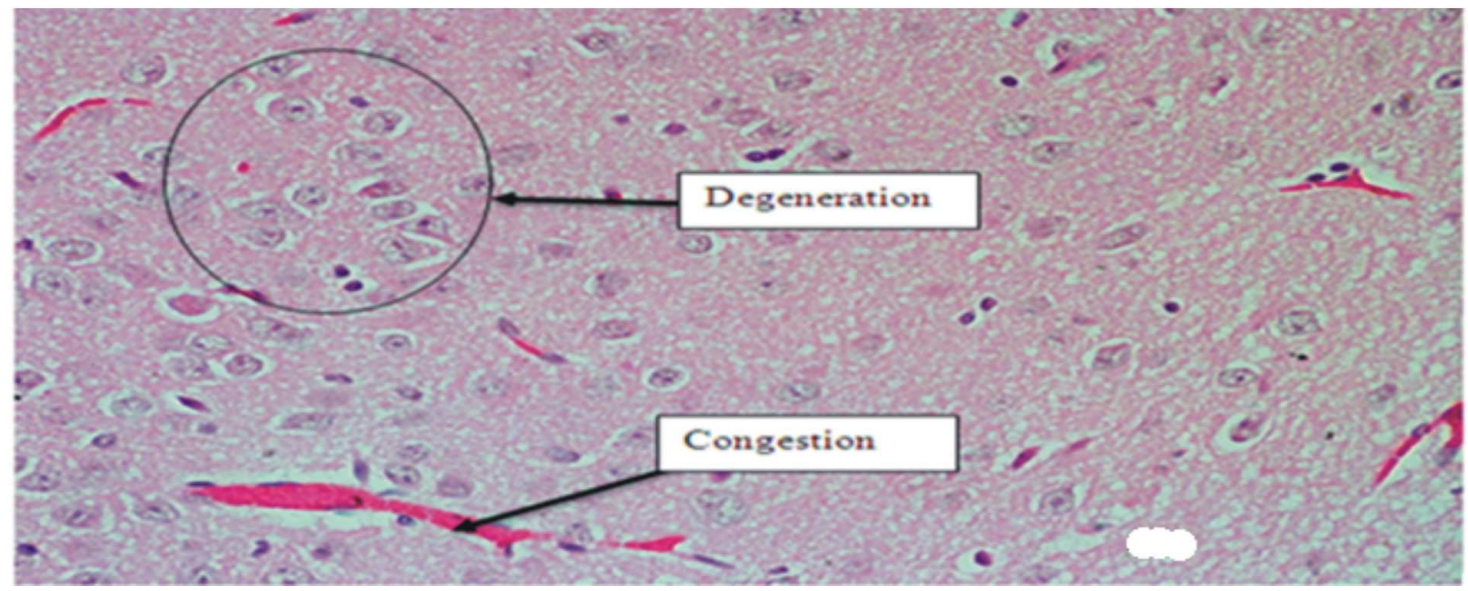

Fig. 16. Photomicrograph section of the pituitary gland which showed congestion of the blood vessels and the ballooning of the cells in female mice inoculated with LPS; H\&E $\times 200$

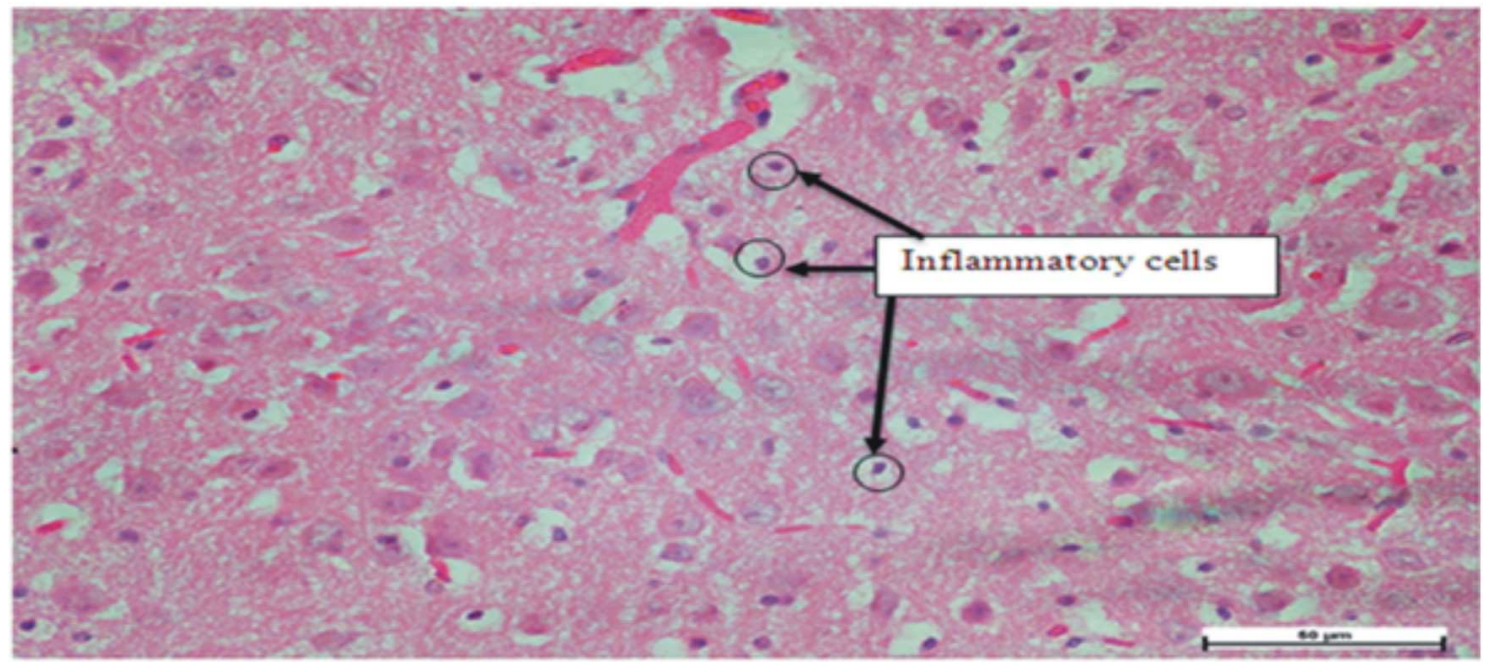

Fig. 17. Photomicrograph section of the pituitary gland which showed the presence of inflammatory cells in female mice inoculated with LPS; H\&E $\times 200$ 


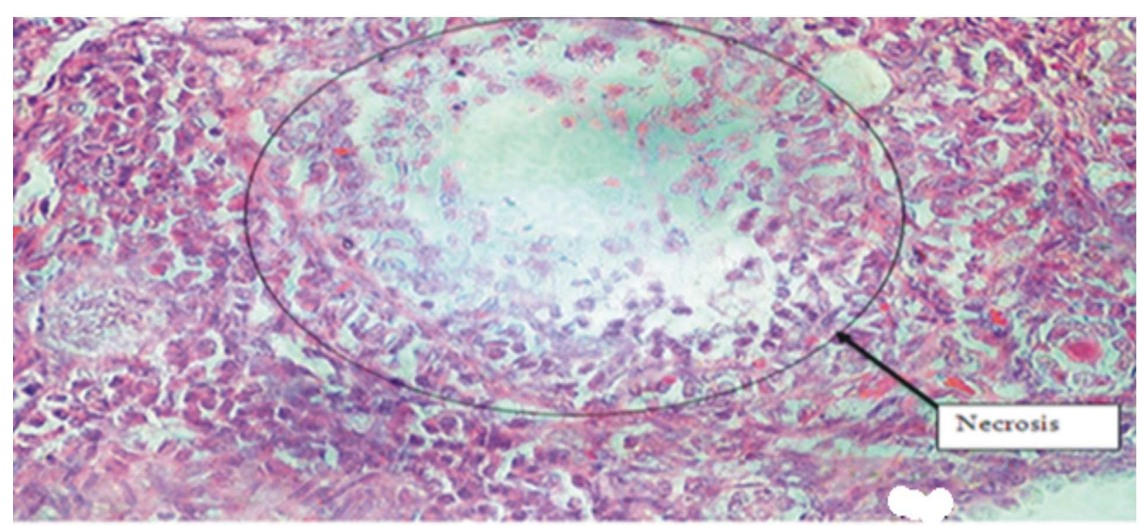

Fig. 18. Photomicrograph section of the Ovary which showed necrosis withe some degree of degeneration in female mice inoculated with LPS; H\&E $\times 200$

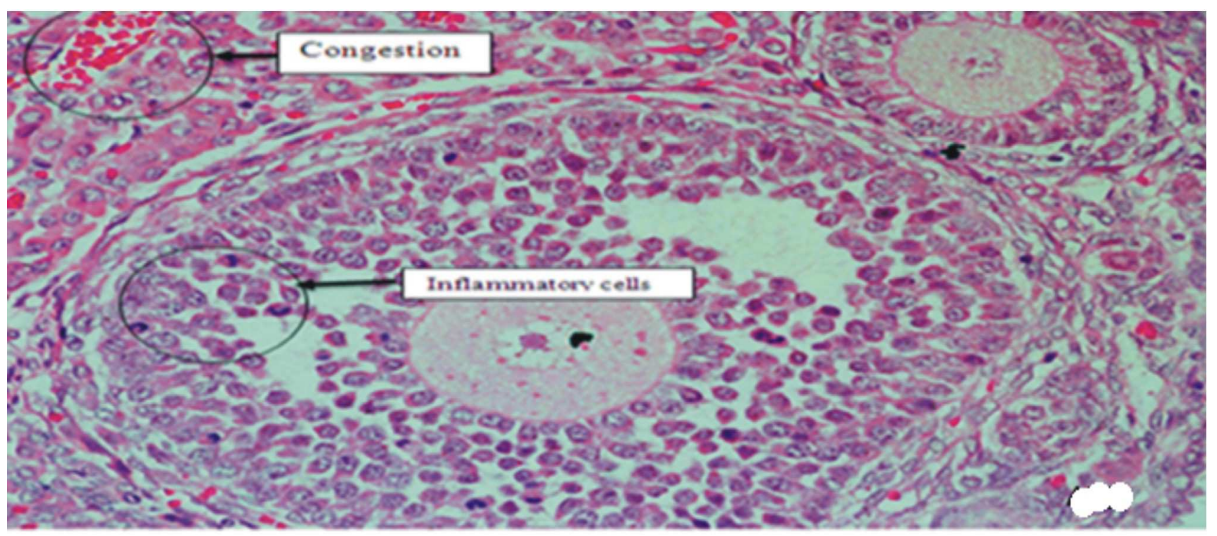

Fig. 19. Photomicrograph section of the Ovary which showed infiltrations of inflammatory cells and the congested blood vessels in the female mice inoculated with LPS; H\&E $\times 200$

Table 1. Kruskal-wallis test comparing scores of histopathological lesions in pituitary glands between groups in the female mice

\begin{tabular}{lllll}
\hline & Necrosis and degeneration & Oedema & Haemorrhage & Inflammatory cells \\
\hline Chi-square & 16.720 & 0.000 & 8.285 & 14.822 \\
df & 2.0000 & 2.000 & 2.000 & 2.0000 \\
P-value & $0.000^{*}$ & 1.000 & $0.000^{*}$ & $0.000^{*}$ \\
\hline
\end{tabular}

*Significant value $\mathrm{p}<0.05$, parameters with significant differences are further analyzed by mann-whitney test

Table 2. Mann-whitney test on comparison of histopathological lesions scoring in pituitary glandsin the female mice

\begin{tabular}{lccr}
\hline Groups & Necrosis and degeneration & Haemorrhage & Inflammatory cells $^{3}$ \\
\hline PBS & $4.75^{\mathrm{a}}$ & $7.25^{\mathrm{a}}$ & $5.00^{\mathrm{a}}$ \\
PM & $18.00^{\mathrm{b}}$ & $15.00^{\mathrm{b}}$ & $16.86^{\mathrm{b}}$ \\
LPS & $14.00^{\mathrm{b}}$ & $14.13^{\mathrm{b}}$ & $12.50^{\mathrm{b}}$ \\
\hline
\end{tabular}

Means ranks ${ }^{\mathrm{a}, \mathrm{b}, \mathrm{c}}$ with different superscript in the same column are significantly different at $(\mathrm{p}<0.05)$ between groups; ${ }^{1,2,3} \mathrm{p}=0.000$ (from kruskal wallis test); Group 1 = Control or Phosphate Buffer Saline (PBS); Group 2 = P. multocida type B: 2 (PM); Group $3=$ Lipopolysaccharide (LPS)

Table 3. Kruskal-wallis test comparing scores of histopathological lesions in ovaries between groupsin the female mice

\begin{tabular}{lcccc}
\hline & Necrosis and degeneration & Oedema & Haemorrhage & Inflammatory cells \\
\hline Chi-square & 16.243 & 0.000 & 2.025 & 5.934 \\
df & 2.000 & 2.000 & 2.000 & 2.000 \\
P-value & $0.000^{*}$ & 1.000 & 0.363 & $0.051^{*}$ \\
\hline
\end{tabular}

*Significant value $\mathrm{p}<0.05$, parameters with significant differences are further analyzed by mann-whitney test 
Table 4. Mann-whitney test on comparison of histopathological lesion scoring in ovariesin the female mice

\begin{tabular}{lr}
\hline Groups & Necrosis and degeneration $^{1}$ \\
\hline PBS & $5.56^{\mathrm{a}}$ \\
PM & $18.50^{\mathrm{b}}$ \\
LPS & $11.29^{\mathrm{c}}$ \\
\hline
\end{tabular}

Means ranks ${ }^{a, b, c}$ with different superscript in the same column are significantly different at $(\mathrm{p}<0.05)$ between groups; ${ }^{1,} p=0.000$ (from kruskal wallis test); Group $1=$ Control or Phosphate Buffer Saline (PBS); Group $2=$ P. multocida type B: 2 (PM); Group $3=$ Lipopolysaccharide (LPS)

\section{Discussion}

This study reports the effects of $P$. multocida type B: 2 and its lipopolysaccharides on reproductive hormones concentrations and histopathological changes in the pituitary glands and reproductive organs in a mouse model.

Oral inoculation with P. multocida type B: 2 and its lipopolysaccharides into mice produced histopathological lesions in the testes. The lesions were more detrimental following inoculation of $P$. multocida type B: 2 relative to its LPS. These could be associated with the pathogenesis and the severity of infections induced by $P$. multocida type B: 2 and its lipopolysaccharides. These findings were similar to the study conducted by (OIE, 2008) following oral inoculation of the bacteria in mice. Similarly, the histopathological lesion in the pituitary gland produced significant changes after oral inoculation of the bacteria compared to the LPS and the most obvious lesion were degeneration and necrosis. This lesion could be associated with the pathogenesis and the severity of the disease in this group of mice. Thus, it may be considered that the bacteria or its endotoxin has affinity towards the hormone producing cells in pituitary glands and also the cells in the testes and ovaries which perchance can activate the infiltration of inflammatory cells to the respective organs. Meanwhile, the endotoxin (LPS) of the bacteria may have direct effects on the cells and may cause septicaemic phase. These findings are in consensus with those of (Eckersall and Bell, 2010).

Testosterone concentration was twofold higher in the $P$. multocida type B: 2 group when compared to the other groups which are not consistent with the histopathological changes of the testes and pituitary gland. The increased level of testosterone production in this group of mice could be related to the reduction in the immune functions of inoculated male mice. Thisfindingwas similar to the study conducted by (Kharb and Charan, 2012) which reported testosterone depletion and testosterone receptor antagonism as responsible for prevention of the depression of immune function. However, in the current study the inoculation of the male mice with LPS indicated drastic reduction in the production of testosterone in this group. On the other hand, inoculation of animals with LPS from these bacteria could be associated with increased immune functions in this group of animals and therefore could stand the chance of a better candidate for vaccine production. Furthermore, inoculation with LPS may induce testicular tissue which may contribute to the low testosterone concentration, as the hormone producing cells have been destroyed or as a result of disruption of the hypo-pituitogonadal axis. In another study by (Abdullah et al., 2013b) showed that low immune performance in male mice has also been correlated with high target organ responsiveness to testosterone.

The mucosal surfaces of the pituitary gland and the female reproductive organs such as the ovaries represent the main area of contact of microbial agents and their endotoxin (LPS) with the body's immune system. The pituitary gland and the ovaries have perchance the most specialized immune system, since it has the twin task of providing incessant defense against the potential pathogens while providing an amenable milieu for the sperm viability. These conditions are maintained by the specific regulation of the immune system by the ovarian hormones estrogen and progesterone. In the current study, female reproductive hormones, progesterone and estrogen concentration levels do showed some changes in the infected female mice with P. multocida type B: 2 and its endotoxin. The higher concentrations of progesterone and lower concentrations of estrogen induced by both $P$. multocida type B: 2 and its LPS may occur because of the damages at the cellular levels observed in hormone producing cells in both ovaries and pituitary glands which contribute to the changes in reproductive hormone production. These findings are similar to the study conducted by (Angele et al., 2000).

Based on the changes that occur in the female mice reproductive hormones, there would perhaps be some uncertainty regarding the reproductive status of the infected or carrier animals. The fertility potentials of these animals may be affected and they may be unable to be pregnant as there are disruptions in the reproductive hormonal levels. In the current study, female mice inoculated with both P. multocida type B: 2 and LPS indicated increased concentrations of progesterone. The increased progesterone concentrations in these groups of 
mice could be indicative of enhanced infections in the female animals if the level of progesterone happened to be amplified by any means. This finding was in agreement to the study conducted by (Charu et al., 2000). Furthermore, the lower concentrations of estrogen induced by both inoculation of $P$. multocida type B: 2 and its LPS in the female mice seems to decrease the susceptibility of the female mice to infections, this could be due to the correlations between the decrease in the concentration of estrogen and the levels of the severity in the histopathological alterations in the pituitary glands and the ovaries of the female mice. This finding was also similar to the study conducted by (Khuder et al., 2012).

\section{Conclusion}

In conclusion, inoculation of $P$. multocida type B: 2 and its endotoxinvia oral route developed significant hispathological changes in the pituitary glands, testes and the ovaries. Similarly, there was significant alteration in the levels of the male and female reproductive hormonesdue to $P$. multocida type B: 2 and its LPS which are imperative considering the potential effects of immune responses of the individual animals. Therefore, the sex hormonal levels in animals could be used to assess the immune statuses of at risk animal population and proffer amenable Veterinary medical care to afflicted animal population.

\section{Acknowledgement}

We thank the staff of the Department of Veterinary Clinical Studies, Universiti Putra Malaysia and Research Centre for Ruminant Disease, in particular Yap Keng Chee, Mohd Jefri Norsidin and Mohd Fahmi Mashuri for their assistance and the Ministry of Education Malaysia.

\section{Conflict of Interest}

The researchers have no conflict of interest.

\section{Funding Information}

We also thank Ministry of Higher Education Malaysia for providing financial aid to conduct this study.

\section{Author's Contributions}

AWH, AAS and FFJA conceptualized and supervised the research. AMMA, YA, AT, KM, LA, MAS, RZ and MJBS collected samples, drafted the manuscript and ran all statistical tests. All authors have read and approved the manuscript.

\section{Ethics}

All procedures and experiments illustrated were undertaken under a project license approved by Animal Utilization Protocol Committee, Faculty of veterinary medicine, Universiti Putra Malaysia, with reference number: PM/IACUC/FYP-2013/FPV.043 and FPV/FYP/2013/059.

\section{References}

Abdullah, F.F.J., M.M. Khaleel, L. Adamu, A.Y. Osman and A.W. Haron et al., 2013a. Polymerase chain reaction detection of Pasteurella multocida type B: 2 in mice infected with contaminated river water. Am. J. Anim. Vet. Sci., 8: 146-151.

DOI: 10.3844/ajavsp.2013.146.151

Abdullah, F.F.J., A.Y. Osman, L. Adamu, M.S.M. Yusof and A.A. Saharee et al., 2013b. Polymerase chain reaction detection of pasteurella multocida type B: 2 in mice following oral inoculation. Asian J. Anim. Vet. Adv., 8: 493-501.

DOI: 10.3923/ajava.2013.493.501

Abubakar, M.S. and M. Zamri-Saad, 2011. Clinicopathological changes in buffalo calves following oral exposure to Pasteurella multocida B: 2 . Basic Applied Pathol., 4: 130-135.

DOI: $10.1111 /$ j.1755-9294.2011.01113.x

Angele, M.K., M.G. Schwacha, A. Ayala and I.H. Chaudry, 2000. Effect of gender and sex hormones on immune responses following shock. Shock, 14: 81-248.

DOI: 10.1097/00024382-200014020-00001

Charu, K., Z. Fan, A.D., Murdin and C.R. Wira, 2000. Effects of estradiol and progesterone on susceptibility and early immune responses to chlamydia trachomatis infection in the female reproductive tract. Infect. Immun., 68: 4207-4216. DOI: 10.1128/IAI.68.7.4207-4216.2000

Eckersall, P.D. and R. Bell, 2010. Acute phase proteins: Biomarkers of infection and inflammation in veterinary medicine. Vet. J., 185: 23-27. DOI: 10.1016/j.tvj1.2010.04.009

Harper, M., A. Cox, B. Adler and J.D. Boyce, 2011. Pasteurella multocida lipopolysaccharide: The long and the short of it. Vet. Microbiol., 153: 109-115. DOI: 10.1016/j.vetmic.2011.05.022

Jamal, H., K.H. Chua, D. Frederick, A.A. Mahmood and I. Salmah, 2005. Plasmid DNA analysis of pasteurella multocida serotype $\mathrm{b}$ isolated from haemorrhagic septicaemia outbreaks in Malaysia. Med. J. Malaysia, 1: 35-39.

Jesse, F.F., S.A. Affandi, A.Y. Osman, L. Adamu and A.A. Saharee et al., 2013. Clinico-pathological features in mice following oral exposure to pasteurella multocida B: 2. IOSR J. Agric. Vet. Sci., 3: 35-39. DOI: 10.9790/2380-0343539 
Khaleel, M.M., F.F.J. Abdullah, L. Adamu, A.Y. Osman and A.W. Haron et al., 2013. Acute phase protein responses in mice infected with river water contaminated by Pasteurella multocida type B: 2. Am. J. Anim. Vet. Sci., 8: 159-164. DOI: 10.3844/ajavsp.2013.159.164

Khaleel, M.M., F.F.J. Abdullah, L. Adamu, Y. Abba and A.W. Haron et al., 2014. Histopathological changes in mice infected with river water contaminated by Pasteurella multocida type B: 2. Am. J. Anim. Vet. Sci., 9: 71-76. DOI: 10.3844/ajavsp.2014.71.76

Kharb, S. and S. Charan, 2012. Mouse model of haemorrhagic septicemia: Dissemination and multiplication of Pasteurella multocida B: 2 in vital organs after intranasal and subcutaneous challenge in mice. Vet. Res. Commun., 37: 59-63.

DOI: $10.1007 / \mathrm{s} 11259-012-9547-5$

Khuder, Z., A.Y. Osman, F.F. Jesse A.W. Haron and R. Abdullah, 2012. Sex hormone profiles and cellular changes of reproductive organs of mice experimentally infected with C. pseudotuberculosis and Its exotoxin phospholipase D (PLD). IOSR J. Agric. Vet. Sci., 1: 24-29.
Moffatt, J.H., M. Harper, P. Harrison, J.D. Hale and J.D. Boyce et al., 2010. Colistin resistance in Acinetobacter baumannii is mediated by complete loss of lipopolysaccharide production. Antimicrob. Agents Chemother., 54: 4971-4977. DOI: 10.1128/AAC.00834-10

Raetz, C.R. and C. Whitfield, 2002. Lipopolysaccharide endotoxins. Ann. Rev. Biochem., 71: 635-700. DOI: 10.1146/annurev.biochem.71.110601.135414

Saharee, A.A., 2006. Haemorrhagic septicaemia in cattle and buffaloes: Are we ready for freedom. Inaugural Lecture, Universiti Putra Malaysia.

Shafarin, M.S., M. Zamri-Saad, K.B. Siti and A.A. Saharee, 2009. Pathological changes in the respiratory tract of goats infected by Pasteurella multocida B: 2. J. Comp. Pathol., 140: 194-197. DOI: $10.1016 /$ j.jcpa.2008.10.005

Boyce, J.D., M. Harper, I.W. Wilkie and B. Adler, 2010. Pasteurella. In: Pathogenesis of Bacterial Infections in Animals, Gyles, C.L., J.F. Prescott, G. Songer and C.O. Thoen (Eds.), Wiley, Ames, ISBN-10: 0470958219, pp: 325-346.

OIE, 2008. Haemorrhagic septicaemia. OIE Terrestrial Manual. 